\title{
In-vitro differentiation of type A spermatogonia in mouse cryptorchid testis
}

\author{
S. Aizawa and Y. Nishimune* \\ Division of Physiology and Pathology, National Institute of Radiological Sciences, Anagawa, \\ Chiba 280 and ${ }^{*}$ Department of Microbial Genetics, Research Institute for Microbial Diseases, \\ Osaka University, Yamadakami, Suita 565, Japan
}

\begin{abstract}
Summary. Cryptorchid testes from adult mice were incubated in calf serumsupplemented medium. There was an effective differentiation of adult type A spermatogonia up to the pachytene stage of meiotic division which resembled the process of spermatogenesis in vivo. In the absence of calf serum, type A spermatogonia did not differentiate at all. They differentiated when the serum was present for the first day, but was absent for the rest of cultivation.

These results indicate that serum is necessary for only the early process of spermatogenesis from type A spermatogonia in vitro and not for the further processes of germ cell differentiation. Type A spermatogonia cultured in serum-free medium retained the ability to differentiate for at least 3 days.
\end{abstract}

\section{Introduction}

It is well known that normal spermatogenesis is regulated by endocrine (Hall, 1970), temperature (VanDemark \& Free, 1970) and nutritional (Leathem, 1970; Ahluwalia \& Bieri, 1971) factors. But the role of such factors in the control of the early stages of spermatogenesis from type A spermatogonia has not yet been clearly defined.

Although the growth and maturation of male mammalian germ cells in vitro has been studied, the initiation of spermatogenesis from undifferentiated type A spermatogonia in adult testis has not yet been shown in culture. This is mainly due to the fact that normal adult testis contains already differentiated cells and there are therefore great difficulties in identifying the cells which have differentiated in vitro from type A spermatogonia.

Experimental cryptorchidism results in a complete sterility (Fukui, 1923; Moore, 1924) due to the deterioration of all the differentiated germ cells (Payne, 1956) except type A spermatogonia (Nishimune, Aizawa \& Komatsu, 1978). Consequently, the cryptorchid testis, containing only type A spermatogonia, could provide a system for the study of germ cell differentiation. The ability of the cryptorchid testis to reinitiate spermatogenesis from type A spermatogonia has already been shown in vivo (Nishimune et al., 1978), and the present report is of an investigation into the differentiation of type A spermatogonia in mouse cryptorchid testis in organ culture.

\section{Materials and Methods}

Animals. Mice of the C57BL strain, reared in our laboratory by brother-to-sister mating, were used. Cryptorchidism was produced by translocation of both testes of 2-month-old animals to the abdominal cavity. After anaesthesia with pentobarbitone sodium, the testes were gently directed through the inguinal canal into the abdomen and then fixed to the abdominal wall by attachment of a small piece of adipose tissue of the caput epididymidis. 
The animals were killed 2 months after operation, and after separation from the tunica albuginea the cryptorchid testes were cut into fragments of approximately $1 \mathrm{~mm}^{3}$. Part of the tissue was fixed immediately for the evaluation of initial histology.

Culture. The culture medium consisted of Eagle's MEM (with $60 \mu \mathrm{g}$ kanamycin $/ \mathrm{ml}$; Nissui Seiyaku Co., Ltd, Tokyo) supplemented with $1 \mathrm{~mm}$-sodium pyruvate, $5 \mathrm{~mm}$-L-glutamine and $0 \cdot 1$ $\mathrm{mm}$ of each of the following amino acids: L-alanine, L-aspargine, L-aspartic acid, L-glutamic acid, glycine, L-proline and L-serine (Steinberger \& Steinberger, 1967). In some tests, 10\% (v/v) calf serum was added to the culture medium. The calf serum (Biken, Osaka) was heat inactivated $\left(56^{\circ} \mathrm{C}\right.$ for $\left.30 \mathrm{~min}\right)$ but not delipidated.

The organ culture method was essentially the same as that described by Steinberger \& Steinberger (1967). For each culture, 16 fragments were arranged on the top of a wire-mesh grid covered with a millipore filter (type HAWP, $0.45 \mu \mathrm{m}$ pore size; Millipore Corp.) in plastic dishes containing sufficient culture medium to moisten the lower surface of the filter. The cultures were incubated at $32.5^{\circ} \mathrm{C}$ in a gas phase of $5 \% \mathrm{CO}_{2}$ and $95 \%$ air. The medium was changed every 3 days.

Histology. Individual tissue fragments were removed from the grid without disturbing the remaining samples. Fragments were fixed in Bouin's solution, dehydrated, embedded in paraffin wax, sectioned at $4 \mu \mathrm{m}$ and stained with Mayer's haematoxylin and eosin. For quantitative assessment of spermatogenetic activity, the numbers of each type of germ cell were counted in relation to 2000 Sertoli cells according to the criteria described by Leblond \& Clermont (1952) and Oakberg (1956a, b). Mitotic prophase, metaphase and anaphase cells were scored as mitotic cells.

Labelling with $\left[{ }^{3} \mathrm{H}\right]$ thymidine and autoradiography. Testicular tissue was labelled by incubating the tissue in medium containing $1 \mu \mathrm{Ci} / \mathrm{ml},\left[6-{ }^{3} \mathrm{H}\right]$ thymidine (sp. act. $14 \cdot 5 \mathrm{Ci} / \mathrm{mmol}$ : New England Nuclear), for $8 \mathrm{~h}$. The labelled fragments were fixed and sectioned, and autoradiography was carried out by the dipping method using the liquid emulsion, NR・M2 (Sakura). After an exposure period of 2 days, the samples were developed, stained with Mayer's haematoxylin and eosin, and subjected to microscopic observation.

\section{Results}

\section{Culture of cryptorchid testes in the presence of $10 \%$ calf serum}

The histological appearance of the cryptorchid mouse testis is shown in Pl. 1, Fig. 1. The seminiferous tubules contained Sertoli cells and type A spermatogonia, but no other germ cells (intermediate, type B spermatogonia, spermatocytes and spermatids). After 3 days in culture, the only germinal elements were type A spermatogonia, some of which showed mitotic figures (Pl 1, Fig. 2). After 6 days, many mitotic cells appeared and, in addition, intermediate and type B spermatogonia were also present in the tubules (Pl. 1, Fig. 3), indicating that the first step of the differentiation of type A spermatogonia had proceeded successfully in vitro. The number of intermediate and type B spermatogonia increased after 9 days and resting primary spermatocytes were beginning to appear (Pl. 1, Fig. 4). After 12 days in culture, a large number of leptotene spermatocytes were seen together with resting primary spermatocytes (PI. 1, Fig. 5). And after 15 days, leptotene and pachytene spermatocytes were seen (Pl. 1, Fig. 6). However, the more mature germ cells were not observed even when cultures were prolonged. These observations indicate that the differentiation of germ cells can proceed from type A spermatogonia to primary spermatocytes in the culture of mouse cryptorchid testis.

As shown by the germ cell counts in Table 1, there was a sequential progression of type A spermatogonia to more mature germ cells. Type A spermatogonia proliferated and differentiated 

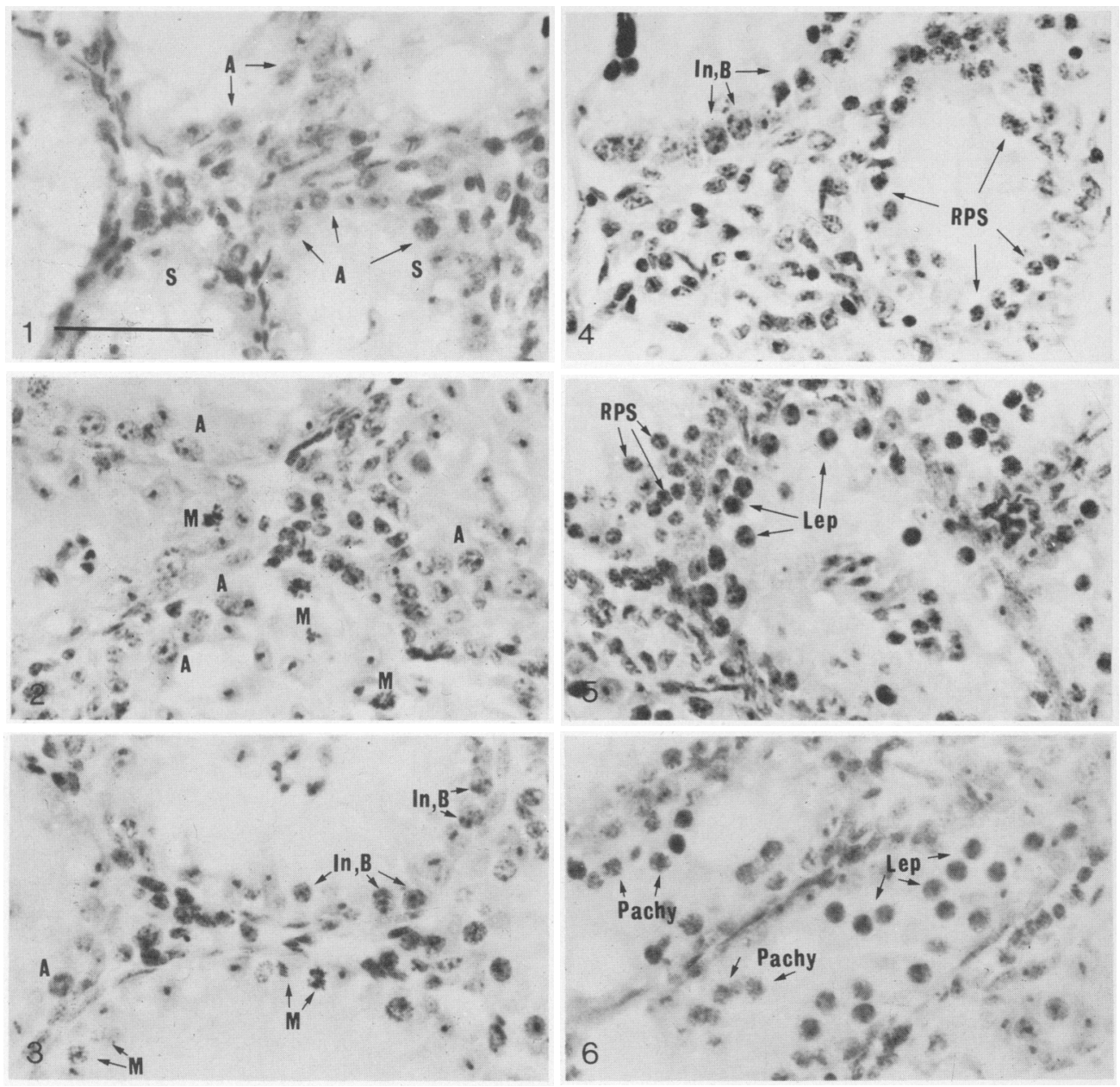

Observations of mouse cryptorchid testicular tissue. The bar represents $50 \mu \mathrm{m}$.

Fig. 1. Testis before cultivation. Seminiferous tubules contain Sertoli cells (S) and type A spermatogonia (A). No other differentiated elements are present.

Fig. 2. Tissue cultured for 3 days in serum-supplemented medium. The only germ cells present are type A spermatogonia (A). Note the mitotic figures (M).

Fig. 3. Tissue cultured for 6 days in serum-supplemented medium. Seminiferous tubules contain intermediate, type B spermatogonia (In, B) and mitotic cells (M).

Fig. 4. Tissue cultured for 9 days in serum-supplemented medium. Seminiferous tubules contain a number of intermediate and type B spermatogonia (In, B). In addition, resting primary spermatocytes (RPS) can be seen.

Fig. 5. Tissue cultured for 12 days in serum-supplemented medium. Leptotene spermatocytes (Lep) and resting primary spermatocytes (RPS) are present.

Fig. 6. Tissue cultured for 15 days in serum-supplemented medium. Seminiferous tubules contain spermatocytes at leptotene (Lep) and pachytene (Pachy). The most advanced germ cells are pachytene spermatocytes. 
Table 1. Kinetics of spermatogenesis from type A spermatogonia in mouse cryptorchid testicular tissue in vitro

No. of differentiated cells*

\begin{tabular}{|c|c|c|c|c|c|c|}
\hline \multirow[b]{2}{*}{$\begin{array}{l}\text { Duration of } \\
\text { culture (days) }\end{array}$} & \multicolumn{2}{|c|}{ Spermatogonia } & \multicolumn{3}{|c|}{ Spermatocytes } & \multirow[b]{2}{*}{ Mitotic cells } \\
\hline & A & Intermediate-B & $\begin{array}{l}\text { Resting } \\
\text { primary }\end{array}$ & Leptotene & $\begin{array}{l}\text { Zygotene- } \\
\text { pachytene }\end{array}$ & \\
\hline \multicolumn{7}{|c|}{ Serum-supplemented culture } \\
\hline 0 & $198 \pm 19$ & $4 \pm 1$ & $5 \pm 3$ & & & $96 \pm 15$ \\
\hline 3 & $342 \pm 13$ & $22 \pm 5$ & & & & $145 \pm 10$ \\
\hline 6 & $239 \pm 7$ & $100 \pm 18$ & $5 \pm 2$ & & & $268 \pm 40$ \\
\hline 9 & $160 \pm 19$ & $640 \pm 150$ & $75 \pm 20$ & & $3 \pm 2$ & $147 \pm 28$ \\
\hline 12 & $132 \pm 14$ & $107 \pm 40$ & $81 \pm 12$ & $600 \pm 97$ & $16 \pm 8$ & $63 \pm 14$ \\
\hline 15 & $169 \pm 10$ & $109 \pm 23$ & $39 \pm 10$ & $309 \pm 52$ & $184 \pm 15$ & $51 \pm 13$ \\
\hline 18 & $150 \pm 20$ & $93 \pm 15$ & $67 \pm 1$ & $103 \pm 9$ & $64 \pm 16$ & $48 \pm 2$ \\
\hline \multicolumn{7}{|c|}{ Serum-free culture } \\
\hline 3 & $236 \pm 16$ & $9 \pm 2$ & $2 \pm 1$ & & & $33 \pm 6$ \\
\hline 6 & $245 \pm 17$ & $17 \pm 11$ & $3 \pm 3$ & $2 \pm 2$ & & $19 \pm 2$ \\
\hline 9 & $135 \pm 24$ & $6 \pm 3$ & & $15 \pm 15$ & & $12 \pm 5$ \\
\hline \multicolumn{7}{|c|}{ Serum-supplemented culture for Ist day only } \\
\hline 3 & $502 \pm 28$ & $10 \pm 7$ & $2 \pm 1$ & & & $264 \pm 58$ \\
\hline 6 & $391 \pm 64$ & $45 \pm 2$ & $14 \pm 8$ & $16 \pm 16$ & $6 \pm 6$ & $136 \pm 19$ \\
\hline 9 & $274 \pm 21$ & $298 \pm 53$ & $108 \pm 21$ & $37 \pm 15$ & $13 \pm 5$ & $84 \pm 10$ \\
\hline 12 & $128 \pm 23$ & $25 \pm 6$ & $31 \pm 16$ & $769 \pm 234$ & $155 \pm 23$ & $13 \pm 5$ \\
\hline \multicolumn{7}{|c|}{ Serum-supplemented culture after first 3 days } \\
\hline 3 & $461 \pm 9$ & $12 \pm 7$ & & & $1 \pm 1$ & $75 \pm 19$ \\
\hline 6 & $385 \pm 12$ & $26 \pm 8$ & $5 \pm 4$ & $8 \pm 4$ & $1 \pm 1$ & $116 \pm 22$ \\
\hline 9 & $252 \pm 13$ & $62 \pm 19$ & $15 \pm 3$ & $30 \pm 16$ & $43 \pm 31$ & $118 \pm 36$ \\
\hline 12 & $245 \pm 46$ & $167 \pm 6$ & $99 \pm 20$ & $20 \pm 6$ & $10 \pm 1$ & $101 \pm 9$ \\
\hline 15 & $269 \pm 6$ & $546 \pm 15$ & $369 \pm 219$ & $271 \pm 39$ & $127 \pm 87$ & $117 \pm 9$ \\
\hline 18 & $230 \pm 86$ & $66 \pm 38$ & $107 \pm 94$ & $745 \pm 95$ & $248 \pm 61$ & $34 \pm 4$ \\
\hline
\end{tabular}

* Counts per 2000 Sertoli cells for mean \pm s.e.m. values for 3 cultures.

synchronously to intermediate and type B spermatogonia in culture. Table 1 also shows that less than a half of the leptotene stage spermatocytes can proceed to pachytene stage spermatocytes, thereby suggesting that differentiation up to leptotene proceeds efficiently but that to pachytene is less effective.

In serum-free medium, however, the numbers of mitotic cells decreased steadily (Table 1). The numbers of type A spermatogonia were increased after 3 and 6 days in culture but there were very few intermediate and type B spermatogonia even after 9 days. Thus, the type A spermatogonia of cryptorchid testes cannot differentiate in serum-free culture. The inactivation

Table 2. Labelling index (no. labelled as \% of the total no.) of type A spermatogonia cultured in media with and without serum supplementation

\begin{tabular}{lccc}
\hline & \multicolumn{3}{c}{ Days in culture } \\
\cline { 2 - 4 } Culture condition & 1 & 2 & 3 \\
\hline With serum & 54,59 & 46,59 & 54,55 \\
Without serum & 56,50 & 22,21 & 13,26
\end{tabular}

Values are from 2 independent cultures. 
of mitosis of type A spermatogonia cultured in serum-free medium was also shown by the decrease in their labelling index (Table 2).

\section{Effect of transient serum supplement}

The results of culture of cryptorchid testicular tissue in serum-supplemented medium for 1 day only before transfer to serum-free medium are shown in Table 1. Type A spermatogonia differentiated with a pattern similar to that when serum was present throughout the experiment, indicating that serum is required only for the early stage of spermatogenesis, i.e. the initiation of the differentiation of type A spermatogonia.

The effect of serum on the appearance of the differentiated cells in culture was further examined by adding serum to the culture for various periods (Table 3 ). The processes initiated during the 3 days from the beginning of cultivation seemed to be highly dependent on serum.

Table 3. Effect of the duration of serum supplementation on the differentiation of type A spermatogonia in mouse cryptorchid testes in vitro

\begin{tabular}{llc}
\hline \multicolumn{2}{c}{ Days of culture } & \\
\hline $\begin{array}{l}\text { With } \\
\text { serum }\end{array}$ & $\begin{array}{c}\text { Without } \\
\text { serum }\end{array}$ & $\begin{array}{c}\text { Total no. of } \\
\text { differentiated cells (\%) }\end{array}$ \\
\hline $0-1$ & $2-9$ & $456 \pm 81(35)$ \\
$0-2$ & $3-9$ & $859 \pm 99(67)$ \\
$0-3$ & $4-9$ & $979 \pm 101(76)$ \\
$0-6$ & $7-9$ & $1224 \pm 351(95)$ \\
$0-9$ & - & $1285 \pm 256(100)$ \\
\hline 4 & $0-3,5-15$ & $135 \pm 13(10)$ \\
$4-5$ & $0-3,6-15$ & $222 \pm 58(18)$ \\
$4-6$ & $0-3,7-15$ & $404 \pm 218(31)$ \\
$4-15$ & $0-3$ & $1312 \pm 79(100)$ \\
\hline
\end{tabular}

Values are mean \pm s.e.m. for 3 cultures, counts per 2000 Sertoli cells.

\section{Ability of type A spermatogonia to differentiate when cultured in serum-free medium}

As shown in Table 1, when cultures were transferred to serum-supplemented medium after being cultivated for 3 days in serum-free medium, type A spermatogonia differentiated to spermatocytes. The sequential appearance of the different types of cells was very similar to that observed in culture supplemented with serum from the start of cultivation. However, the time necessary for the appearance of each type of cells was longer. For example, intermediate and type B spermatogonia were maximal at 12 days after the transfer to serum-supplemented medium, compared with 9 days for culture totally with serum. In spite of this delay, the total number of differentiated cells observed was comparable (Table 1) and type A spermatogonia must remain capable of differentiation in serum-free medium for at least 3 days. When cultures were supplied with serum 1, 2 or 3 days after 3 days of cultivation in serum-free medium, the percentages of differentiated cells appeared much lower than those achieved during culture with serum present from the beginning of cultivation (Table 3 ). Thus type A spermatogonia cultured in serum-free medium for 3 days retained the capability for differentiation but the dependency on serum increased, i.e. differentiation required a longer period of serum supplement. 


\section{Discussion}

The study of the differentiation process using adult testes is inevitably complicated by the presence of a mixed population of germ cells as compared with the study using cryptorchid testes in which the system contains only type A spermatogonia. By using organ culture of the cryptorchid testes of mice, we have demonstrated that type A spermatogonia can differentiate in culture and that serum is necessary for the early stage of differentiation. The pattern of the differentiation of type A spermatogonia in culture seems to be similar to that of normal spermatogenesis in vivo (Table 1), although the process appears to be discontinuous, showing only one wave of fairly synchronous differentiation. This is in contrast with the germ cell differentiation of normal adult testes or the differentiation of type A spermatogonia in surgically reversed cryptorchid testes in vivo in which the numbers of germ cells increase up to and remain at plateau values (Nishimune $e t$ al., 1978). The loss of the ability of germ cells to differentiate continuously is ascribed to the failure of a new supply of cells by continued division of type A spermatogonia (Table 1), but the reason for this is not yet known.

It is possible that the type A spermatogonia require serum for in-vitro cell division because serum has cell division-stimulating activity on various cultured cells. On the other hand, a few type A spermatogonia continued to show $\left[{ }^{3} \mathrm{H}\right]$ thymidine uptake even in serum-free culture for 3 days (Table 2), indicating that they are in $S$ phase in the cell cycle. We have not yet clarified the fate of such type A spermatogonia in serum-free medium, but they must have stopped between $\mathrm{S}$ and $M$ phase, because the mitotic index was very low in serum-free medium (Table 1). Thus, the stimulatory effect of serum on the cell division of type A spermatogonia may act between the $S$ and $M$ phases in cell cycle.

Although the differentiation of type A spermatogonia requires serum in culture, the specific component involved has not yet been determined. Preliminary studies show that the substance(s) in calf serum which promote germ cell differentiation is non-dialysable against phosphatebuffered saline $\left(\mathrm{pH} \mathrm{7.2)}\right.$, heat-stable at $56^{\circ} \mathrm{C}$ for $30 \mathrm{~min}$, and partly labile at $66^{\circ} \mathrm{C}$ for $30 \mathrm{~min}$. Isolation of the active substance(s) is now in progress.

Our observation that serum is required for the early stage of spermatogenesis is in contrast with the reports by Steinberger \& Steinberger $(1966,1967)$ that the germ cell differentiation can be achieved in chemically defined media without serum in immature testes and in normal adult testes. This discrepancy may arise from the difference between type A spermatogonia in cryptorchid testes and gonocytes in immature testes, since the differentiation of the latter may progress differently from that of type A spermatogonia in the cryptorchid testis. Furthermore, it is possible that Steinberger \& Steinberger $(1966,1967)$ were observing the differentiation from type B spermatogonia which has been shown to be serum-independent in our study (Table 1).

We thank Dr A. Matsushiro for discussion, Dr K. Sato and Dr S. Tanemura for reading the manuscript.

\section{References}

Ahluwalia, B. \& Bieri, J.G. (1971) Local stimulatory effect of vitamine A on spermatogenesis in the rat. $J$. Nutrition 101, 141-152.

Fukui, N. (1923) On the action of heat rays upon the testicle: An histological, hygienic, and endocrinological study. Acta scholae medicinalis Univ. Imp. Kioto. 6 fasc. 2, 225-258.
Hall, P.F. (1970) Endocrinology of the testis. In The Testis, vol. 2, pp. 1-71. Eds A. D. Johnson, W. R. Gomes \& N. L. VanDemark. Academic Press, New York.

Leathem, J.H. (1970) Nutrition. In The Testis vol. 3, pp. 169-205. Eds A. D. Johnson, W. R. Gomes \& N. L. VanDemark. Academic Press, New York. 
Leblond, C.P. \& Clermont, Y. (1952) Definition of the stages of the cycle of the seminiferous epithelium in the rat. Ann. N.Y. Acad. Sci. 55, 548-573.

Moore, C.R. (1924) Heat application and testicular degeneration: the function of the scrotum. Am. $J$. Anat. 34, 337-358.

Nishimune, Y., Aizawa, S. \& Komatsu, T. (1978) Testicular germ cell differentiation in vivo. Recovery from artificial cryptorchidism by surgical reversal. Fert. Steril. 29, 95-102.

Oakberg, E.F. (1956a) A description of spermiogenesis in the mouse and its use in analysis of the cycle of the seminiferous epithelium and germ cell renewal. Am. J. Anat. 99, 391-414.

Oakberg, E.F. (1956b) Duration of spermatogenesis in the mouse and timing of stages of the cycle of the seminiferous epithelium. Am. J. Anat. 99, 507-516.
Payne, J.M. (1956) The degenerative changes in the adult mouse testis returned to the abdominal cavity. J. Path. Bact. 71, 117-125.

Steinberger, A. \& Steinberger, E. (1966) Stimulatory effect of vitamines and glutamine on the differentiation of germ cells in rat testes organ culture grown in chemically defined media. Expl Cell Res. 44, 429435.

Steinberger, A. \& Steinberger, E. (1967) Factors affecting spermatogenesis in organ cultures of mammalian testes. J. Reprod. Fert., Suppl. 2, 117124.

VanDemark, N.L. \& Free, M.J. (1970) Temperature effects. In The Testis, Vol. 3, pp. 233-312. Eds A. D. Johnson, W. R. Gomes \& N. L. VanDemark. Academic Press, New York.

Received 24 July 1978 